Journal of Contemporary Research in Social Sciences

ISSN : 2641-0249

Vol. 4, No. 1, pp. 1-9.

2022

Publisher: Learning Gate

DOI: 10.33094/2641-0249.v4i1.161

(C) 2022 by the authors; licensee Learning Gate

\title{
The Influence of Budget and Financial Control in Selected Government Parastatals in Nigeria
}

\author{
AJAYI Ibidolapo Ezekiel ${ }^{*}$ \\ Department of Finance, Faculty of Management Sciences, Ekiti State University, Nigeria. \\ Email: ajayi.ibidolapo@elksu.edu.ng (*Corresponding Author) \\ DADA Samuel Obafemi \\ Department of Finance, Faculty of Management Sciences, Ekiti State University, Nigeria. \\ Email:samuel.dada@eksu.edu.ng
}

Received: 18 October 2021; Revised: 22 November 2021; Accepted: 10 December 202 1; Published: 27 December 2021

Abstract: The study examined budget and financial control in selected government parastatals in Nigeria. The survey research design was adopted in the study. Primary data was obtained using a well-designed questionnaire. Data gathered in the study was analyzed using descriptive, correlation analysis, logit regression analysis and other post estimation tests. Findings obtained in the study indicated that budget preparation exerts insignificant positive impact on financial control in Nigerian government parastatals with coefficient estimate of .034178 ( $p=0.195>$ 0.05); budget implementation exerts insignificant positive impact on financial control of Nigerian government parastatals with coefficient estimate of $.0082354(p=0.750>0.05)$ and budget monitoring and evacuation exert insignificant positive impact on financial control, with coefficient estimate of .0468773 ( $p=0.234>0.05)$. Premise on these findings, the study concluded that financial control on the average tends to increase as government parastatals experience effectual budget performance, with more budget preparation, implementation and monitoring and evaluation as opposed to the usual neglect of budget after implementation. Hence, it was suggested that government should ensure improvement in budget design; government should ensure adequate budget monitoring procedure and government should ensure viable budget evaluation procedure.

Keywords: Budget, Budget implementation, Budget monitoring, Evaluation, Budget preparation, Financial control.

\section{Introduction}

The increasing height of financial fraud among government officials and political office holders across countries all over the world has attracted close concern by numerous scholars over the years. The pace of corruption and abhorrent financial activities that characterizes numerous African countries especially Nigeria has again emphasized the urgent need for financial control which undoubtedly occasions financial accountability and quality stewardship in Nigerian government parastatals (Adeyemi \& Olanrewaju, 2019). Consequent upon these increasing financial impropriety and its resultant effect which marred the efficiency and productivity of individual and government businesses, close attention have been given to financial control and proper use of public funds across nations of the world and hence the adoption of budget. Budget is an important policy instrument for public management as well as proper management of any profit and non-profit making organizations; it is already a common activity in most organizations as it is employed by individuals, corporate firms and government parastatals (Lambe, Lawal, \& Okoli, 2015).

According to Lambe (2014), budget refers to a detailed and coordinated plan designed by the management of an organization and presented in financial terms towards efficiently managing the 
operational activities and resources of the organization for a given period in the future. It could also be described as a plan suggesting how resources will be acquired and consumed over a certain period of time. Institute of Cost and Management Accountant (1999) also conceptualized budget as a plan measured in monetary terms created and approved before a certain time period; basically, it involves a projected income and expenditure to be incurred at the specified period as well as the capital to be invested to attain a given objective. The success and significance of budget is associated with proper recognition of organizational goals, assignment of responsibilities and ensuring prompt execution and satisfactory result towards the attainment of identified goals (Drake \& Fabozzi, 2010).

Budget undoubtedly forms part of management control tools created to encourage efficient use of resources and promoting other significant functions triggering efficiency in government parastatals. The role of budget in government parastatals cannot be overstated as it remains a formal tool that aids adequate planning and control procedure aimed at satisfying the function and responsibilities government parastatal represents (Faleti, Faleti, \& Ojeleke, 2014). Public budget is one noticeable tool that helps in aiding efficient mobilization and allocation of resources while occasioning proper fiscal and economic management. It represents an economic tool deployed for facilitating and achieving the goals of government in a specific fiscal year; for budget to serve as an effective tool in public sector, proper linkages and control of all the parts of budgeting is highly necessary (Faleti et al., 2014).

Although public-sector maintains the same features as private-sector budgets; hence in the bid to satisfactorily instill financial control and financial propriety, it has to be properly created and implemented effectively and efficiently while adequate monitoring is maintained, the performance of the budget must be effectively assessed (Olomola, 2009). Budget if administered properly guarantees adequate management planning, provides framework suitable for evaluating performance and encourages effective coordination and financial control in various segments of any organization (Ahrens \& Chapman, 2006; Yang, 2010).

Financial control activities refer to policies and processes that ascertain the implementation of management directives (Walters \& Dunn, 2001). Adequate control of financial decisions concerns the organization, procedures, methods and internal audit designed by the administration in the quest to cause activities to be executed in adherence to the purpose of the administration and prescribed policies and legislations (Avery \& Obah, 2018). Again, proper financial control ensures that assets and resources are secured, accounting records are accurately kept up-to-date and management information is served in the most reliable manner (Khoove, 2010). Therefore, controls of the financial decisions and activities of government parastatals in respect to the income, expenditure, assets and liabilities that concerns their compliance with the budget, budget component, amount budgeted, expenditure and financing plan of the administration describes an efficient financial control; this suggests that budget is the main precursor for financial control required in government parastatals for accountability, standardized and quality service delivery (Avery \& Obah, 2018).

The quest for accountability, increased efficiency and optimal service delivery in government parastatals in Africa and especially Nigeria brings most government businesses to the fore in the establishment of financial control (Adongo \& Jagongo, 2013). However, the get rich quick idea in Nigeria has in recent times have created a gang of desperados including individuals especially public officers in government parastatals. Government officials have consistently associated themselves to numerous financial improprieties in the bid to satisfy their cravings of attaining material wealth usually with theft from the treasury, utter mismanagement of public funds, abandoned capital project stemming from the little attention given to budgeting and in effect, improper allocation of resources and several other forms of corrupt practices that has dominated government parastatals in Nigeria (Owojori \& Asaolu, 2009).

The height of these disgraceful acts have been affirmed in Nigerian public sectors where public officers and politicians who swore to be of good conduct and deliver the people instead of further impoverishing them are observed to be unaccountable and completely lack transparency; evidently, the misappropriated billions of pension funds of the Nigeria civil service under the watch of Alhaji Maina, 
the discovered N123 billion looted by the Head of the Civil Service of the Federation between 2009 and 2010 and numerous others demonstrates the height of limited financial control observed in government parastatals in Nigeria (Fasua \& Osifo, 2016; The Punch Newspaper, 2016). Numerous public sector reform programmes have been carried out in emerging countries in the $21^{\text {st }}$ century; these programmes and most importantly budgetary system were introduced by the need to observe the New Public Management (NPM) scheme aimed at ensuring improved accountability and instilling public confidence in government parastatals. Despite the all-important attention required by the status quo in Nigerian government parastatal, budgeting which is considered the best bet to correcting the anomalies has received too many complains concerning non-release, partial release or complete delay in release of approved bill for public expenditure; this which is birthed by untimely budget preparation describes how much Nigerian budgeting system has been abused and consequently impairs adequate financial control required to curb corrupt practices in government parastatals (Faleti et al., 2014).

This by implication affected the timely implementation of budget which has over time in Nigeria limited the performance of budget as its accomplishment has been very doubtful in government parastatals (Olurankinse, 2012). Again, the untimely delivery of monthly returns to the office of the Auditor General of the Federation (OAGF) by ministries, departments and agencies has also posed inadequate monitoring and evaluation of the performance of the budget and consequently causing delayed publication of the budget; these have further made the accomplishment of budget far reached thereby occasioning worsening level of financial impropriety in Nigerian government parastatals (Olaoye \& Ogunmakin, 2014). Although numerous studies have been carried out in the discussion of budget and public sector performance; however, most studies observed in literature opine that the association between budget and financial accountability cannot be ascertained (Alade, Owabumoye, \& Olowookere, 2020; Ironkwe \& Okiakpe, 2017; Umeileka, 2013). It is undoubted that financial control precedes accountability and the eventual performance of government parastatals; hence it has become urgent to examine the influence of budget and financial control in selected government parastatals in Nigeria.

\section{Literature Review}

\subsection{Budget}

A budget describes a quantitative expression of idea created for an organization towards giving it an aid to execute specific functions including expenses, production, sales and for other activities such as man power planning, operational activities among others (Alade et al., 2020). Budget involves the creation of expected goals, the delivery of status report concerning current performance results and assessment of performance relative to expected goals. International City/County Management Association (ICMA) (2013) referred budget to as a plan measured in monetary values, developed and acknowledged before a specified period of time which often demonstrate the projected income to be realized and expenses to be experienced during a period as well as the financial resource to be deployed to achieve set objectives. Budget can as well be related to a tool employed to attain relatively higher operational standards and ultimately, the attainment of sound efficiency in the organizational; it describes urgent tasks including the height of spending and approach to adopt in financing and management of resources towards the achievement of organizational goal (Aliyu, 2019).

\subsection{The Budget Process}

The several activities from budget idea to evaluation refer to as budget process. Again, it is a set of related activities and series of actions through the ambit of examining expenditure needs, deploying resources to satisfy the needs as well as evaluate and control expenditure (Osanyintuyi, 2007). The stage that forms the budget stages are not stand-alone activities as there may exist activities associate to several stages of the budget process occurring at the same time and the activities of stage one might noticeably influence the effectuality of others. However, the following are the basic processes of budget: 
Budget Preparation/Formulation: In the public sector, this describes the creation of the budget by the executive arm of government; this stage usually takes place behind closed doors. Expectedly, the legislature and the civil society are constrained from observing this stage of the budget process. According to Olomola (2009) this stage of budget process is related with several weaknesses including improper demonstration of the aims of consultation, reduced scope of relevant issues, cascading enthusiasm of participants and unachievable budget period.

Budget Implementation: The implementation is the second stage of the budget process; it is an executive that concerns the adoption of the budget as accredited by the legislative body (Aborisade, 2008). Budget implementation is concerned with the total change of numbers in the original budget into the practical delivery of resources required to effectively attain organizational objectives. The implementation of budget in Nigeria utterly lack transparency and several weaknesses dominates this stage; they include late disbursement of funds, neglect of budgetary policies, disregard of estimates specified in the budget, instability of appropriated funds disbursed among others (Olomola, 2009).

Budget Monitoring and Evaluation: Budget monitoring is yet another function in the budgetary stages which describes an organization gathering of data on certain proxies to supply management and key stakeholders with the current developmental project with evidences of the level of progress, attainment of objectives and most importantly the progress attained with the use of budgeted funds (Jatau, 2008). He further asserts that the monitoring and evaluation stage assesses whether the amount for certain projects have been judiciously used for the intended purpose which suggests budget effectiveness; the stage also affirms whether public funds disbursed for certain purpose have been used as expected and beneficiaries have been satisfied.

\subsection{Financial Control}

Financial control refers to the approach occasioned to secure assets and ascertain that all financial activities are put on record towards restricting and curbing fraud and error in an organization (Block \& Geoffrey, 2008) According to Okezie (2004), financial control is the process that ensures that financial resources are sources economically and used effectually towards achieving organizational goals and objectives. Financial control is composed mainly of revenue control and expenditure control; revenue control refers to the process that is observed towards ensuring that the sources of income of an organization are sustained per time while expenditure control describes the series of actions adopted so as to ensure that organizations' expenditures are wholly, reasonably, exclusively and necessarily spent for the aim in which it funds was disbursed for (Adams, 2014).

\section{Methodology}

This study adopted the survey research design integrating both qualitative and quantitative methods. The study's population covers all government parastatals in Ekiti State. The purposive sampling technique was employed in sampling Ministry of Budget and Finance and Economic Planning in Ekiti State, Ondo State and Oyo State; furthermore, the random sampling technique was used in selecting three hundred (300) staffs from the sampled government parastatal. A five point likert scale questionnaire is harnessed in amassing primary data for the study.

\subsection{Model Specification}

This study will employ a logistic regression model, in the quest to investigate budget and financial control in selected government parastatals in Nigeria. The study will specifically track the relationship between budget preparation, budget implementation and budget monitoring and evaluation with financial control in Nigeria. The model is specified in Logit form below:

$L=\ln \left(\frac{P_{i}}{1-P_{i}}\right)=\beta_{0}+\beta_{1} B U P+\beta_{2} B U I+\beta_{3} B M E+U$

Where: 


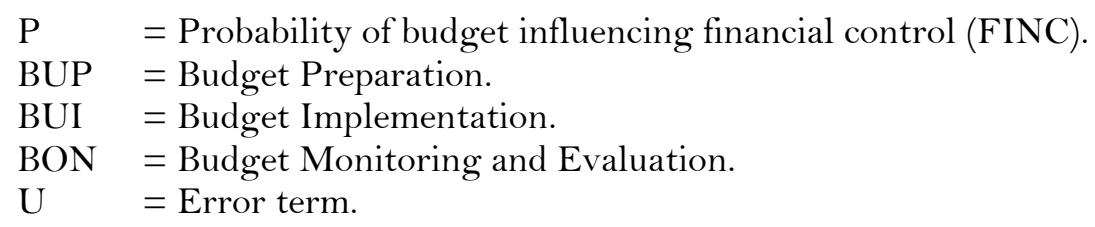

Table-4.1.

Demographic data of respondents.

\begin{tabular}{|c|c|c|c|}
\hline Variable & Detail & Frequency & Percentage \\
\hline \multirow[t]{3}{*}{ Gender } & Male & 171 & 57.0 \\
\hline & Female & 129 & 43.0 \\
\hline & & 300 & 100 \\
\hline \multirow[t]{4}{*}{ Age } & 18-28 Years & 45 & 15.0 \\
\hline & 29-38 Years & 168 & 56.0 \\
\hline & 39 Years and Above & 87 & 29.0 \\
\hline & & 300 & 100 \\
\hline \multirow[t]{5}{*}{ Qualification } & O'Level & 45 & 15.0 \\
\hline & $\mathrm{NCE} / \mathrm{OND}$ & 85 & 28.0 \\
\hline & First Degree & 84 & 28.0 \\
\hline & M.Sc \& Above & 86 & 29.0 \\
\hline & & 300 & 100 \\
\hline \multirow[t]{5}{*}{ Marital Status } & Single & 51 & 17.0 \\
\hline & Married & 138 & 46.0 \\
\hline & Divorced & 78 & 26.0 \\
\hline & Separated & 33 & 11.0 \\
\hline & & 300 & 100 \\
\hline \multirow[t]{4}{*}{ Work Experience } & $1-3$ years & 135 & 45.0 \\
\hline & 4-6 years & 84 & 28.0 \\
\hline & 7 years and Above & 81 & 27.0 \\
\hline & & 300 & 100 \\
\hline
\end{tabular}

Source: Field Survey, 2021.

\section{Data Analysis and Discussion}

Table 4.1 presents the distribution of respondents by sex. The table reveals that 171 representing $(57 \%)$ of the respondents are male, while $129(43 \%)$ are female. Though the distribution is more of male than female, however there is no evidence of gender bias, as the difference may be attributed to the fact that there are more male academics than female in general. However, it was revealed that 45 representing $15 \%$ of the respondents fall with the age range of $18-28$ years, 168 representing $56 \%$ of the respondents falls within 29-38 years while 87 representing 29\% are 39 years and above. Again, findings from Table 4.1 suggests that $61(17 \%)$ of the respondents are single, 138(46\%) are married, $78(26 \%)$ are divorced while $33(11 \%)$ are separated. It is observed $45(15.0 \%)$ of the respondents are O'Level Holders, $85(28 \%)$ are OND/HND certificate holders, $84(28 \%)$ of the respondents are B.Sc certificate holders while $86(29 \%)$ of the respondents holds M.Sc certificate. Lastly, over 130 staffs (45\%) have spent less than 5 years on the job, $84(28 \%)$ have spent between 4-6 years on the job, $81(27 \%)$ have spent between 7 and above. 
Table-4.2.

Correlation Matrix.

\begin{tabular}{c|c|c|c|c}
\hline & FINC & BUP & BUI & BON \\
\hline FINC & 1.000000 & & & \\
\hline BUP & 0.792408 & 1.000000 & & \\
\hline BUI & 0.814786 & 0.882767 & 1.000000 & \\
\hline BON & 0.825720 & 0.930299 & 0.953775 & 1.000000 \\
\hline
\end{tabular}

Correlation statistics reported in Table 4.2 stood at $0.7924,0.8147,0.8257,0.8827,0.9302,0.0937$ for FINC and BUP, FINC and BUI, FINC and BON, BUP and BUI, BUP and BON, BUI and BON respectively. Notably the result showed that there is strong positive correlation between financial control, budget preparation, budget implementation and budget monitoring and control of staffs in government parastatals in Nigeria.

\subsection{Analysis of the Impact of Compensation Packages on Staffs Performance in Government Parastatals in Ekiti} State

Table-4.3.

Logistic Regression Estimates.

\begin{tabular}{c|c|c|c|c}
\hline Variable & Coefficient & Std. Error & Z-test stat & Probability \\
\hline C & 0.3418153 & 0.6222601 & 0.55 & 0.583 \\
\hline BUP & 0.034178 & 0.026388 & 1.30 & 0.195 \\
\hline BUI & 0.0082354 & 0.258676 & 0.32 & 0.750 \\
\hline BON & 0.0468773 & 0.0393569 & -1.19 & 0.234 \\
\hline
\end{tabular}

Note:

LR chi2 $(5)=2.88$, Prob=0.0112, Pseudo R-square $=0.8310$

* connote significance at $5 \%$ level of significant.

Estimation result presented in Table 4.3 reported coefficient estimates of the logistic model specified in the study to examine budget and financial control in selected government parastatals in Nigeria. Result showed that budget preparation exerts insignificant positive impact on financial control with coefficient estimate of .034178 ( $\mathrm{p}=0.195>0.05)$, impact of budget implementation on financial control is positive but insignificant, with coefficient estimate of $-.0082354 \quad(\mathrm{p}=0.750>0.05)$, while budget monitoring and evaluation exert insignificant positive impact on financial control, with respective coefficient estimate of $.0468773(\mathrm{p}=0.234>0.05)$. Likelihood ratio statistics and the corresponding probability value showed that the model is a good fit with Pseudo R-square reflecting that about $83 \%$ of the systematic variation in financial control in Nigeria can be explained by budget preparation, budget implementation and budget monitoring and evaluation.

Table-4.4.

Marginal Effect Estimates.

\begin{tabular}{c|c|c|c|c}
\hline Variable & $\mathbf{d y} / \mathbf{d x}$ & Std. Error & Z-test stat & Probability \\
\hline BUP & 8.412307 & 0.00000 & -0.99 & 0.320 \\
\hline BUI & 3.362107 & 0.00000 & -1.49 & 0.135 \\
\hline BON & 1.824507 & 0.00000 & 0.24 & 0.811 \\
\hline
\end{tabular}

\subsection{Marginal Effect Analysis}

Marginal effect estimation result presented in Table 4.4 revealed in more concise term the impact of the explanatory variables on the dichotomous dependent variable (financial control). In specific term marginal effect estimation reflects the changes in the probability of highly influence financial control with respect to changes in the explanatory variables. As reported in Table 4.4 probability of highly 
influence control increases by 8.412307, 3.362107 and 1.824506 for every increase in budget preparation, budget implementation and budget monitoring and evaluation respectively.

\subsection{Post Estimation Test}

Before the estimated logistic regression model can be used for statistical inference it is expedient to ascertain whether the model fit sufficiently well. This is done by testing whether the model satisfy assumptions of binary response model. Post estimation tests conducted in the study include tests geared toward ascertaining whether the model is correctly specified, whether the overall model is statistically significant, and whether the regressors are orthogonal (Uncorrelated). Hence the specification test, goodness of fit test and multicollinearity test presented in Tables 4.5, 4.6, and 4.7 respectively.

Table-4.5.

Specification Test Result.

\begin{tabular}{c|c|c|c|c}
\hline Statistics & Coefficient & Std.Error & Z-test & Probability \\
\hline C & -.1218099 & 0.1773927 & -0.69 & 0.492 \\
\hline _hat & 1.348696 & 0.5944896 & 2.27 & 0.023 \\
\hline _hatsq & 1.558166 & 1.345744 & 1.16 & 0.247 \\
\hline \multicolumn{2}{l}{ Note: *onnotes significance at 5\% level of significance. }
\end{tabular}

Specification test result presented in Table 4.5 reported hat, and hatsq statistics of 1.348696 and 1.558166 alongside probability values of 0.023 and 0.247 respectively. The reported probability values revealed that the model is correctly specified, with hat statistics significant as expected and hatsq insignificant as expected.

Table-4.6.

Goodness of Fit.

\begin{tabular}{c|c}
\hline Hosmer-Lemeshow $\operatorname{chi} 2(8)$ & 12.90 \\
\hline Prob $>$ chi2 & 0.1152 \\
\hline
\end{tabular}

The reported Hosmer-Lemeshow statistics in Table 4.6 stood at 12.90 alongside probability value of 0.1152. By standard the fitness of the model is confirmed when the reported Hosmer-Lemeshow statistic is not statistically significant, which implies there is no significance difference between the observed frequency and predicted frequency. Reported Hosmer-Lemeshow statistic and the corresponding probability value validate that the observed frequency of the model and the predicted frequency match closely, thus the model is a good fit.

Table-4.7.

Collinearity diagnostic test.

\begin{tabular}{c|c|c}
\hline Variable & VIF & Tolerance \\
\hline SAL & 1.22 & 0.8212 \\
\hline INCEN & 1.05 & 0.9496 \\
\hline BON & 1.17 & 0.8577 \\
\hline
\end{tabular}

Table 4.7 present result of multi-collinearity test conducted to confirm the level of orthogonality of the explanatory variable. The table reports tolerance and variance inflation factor (VIF) for each of the explanatory variables included in the model. Overview of the result showed that both variance inflation factors and tolerance statistics reported for each of the variables are not too far from 1 which is the threshold for perfect orthogonality (no correlation), thus the result revealed that there is no evidence of 
severe multi-collinearity between pairs of explanatory variables used in the estimated model. Hence the regressors are orthogonal (uncorrelated).

\section{Discussion of Findings}

The estimations presented above which evidenced the result of analysis conducted in the study to track the relationship between of budget such as budget preparation, budget implementation and budget monitoring and evaluation with financial control; the following discoveries were made: First the study found from the correlation analysis conducted in the study that there is positive correlation between salary budget preparation, budget implementation and budget monitoring and evaluation and financial control. On the second ground the study found that budget preparation exerts insignificant positive impact on financial control in Nigerian government parastatals with coefficient estimate of .034178 $(\mathrm{p}=0.195>0.05)$, which implies that financial control in government parastatals on the average tends to increase as the adoption of budget predation increases. The study also revealed that budget implementation exerts insignificant positive impact on financial control of Nigerian government parastatals with coefficient estimate of $.0082354(\mathrm{p}=0.750>0.05)$. On the other the study found that budget monitoring and evaluation exert insignificant positive impact on financial control, with coefficient estimate of $.0468773(\mathrm{p}=0.234>0.05)$. The study showed that while impact of surrogates of budget like budget preparation and budget implementation on financial control is positive and insignificant, impact budget monitoring and evaluation in negative though there is no evidence that it is significant.

\section{Conclusion and Recommendations}

Premised on the findings, obtained in the study it is concluded that financial control on the average tends to increase as government parastatals experience effectual budget performance, with more budget preparation, implementation and monitoring and evaluation as opposed to the usual neglect of budget after implementation. Adequate evidence established that budget significantly influence financial control in government parastatal; this suggest that high level of financial control will be attained among government parastatals in Nigeria if the potentials of budget is fully explored. Following this conclusion, the study suggested that:

i. Government should ensure improvement in budget design as it has proved to have positive impact on financial control in government parastatals.

ii. Government should ensure adequate budget monitoring procedure in other to ensure revenue and expenditure are been made to the budgeted areas and for effective financial control in government parastatals.

iii. Government should ensure viable budget evaluation procedure in other to ensure the resources are been disbursed to appropriate quarters as budgeted and effectively control financial aspect in government parastatals.

\section{References}

Aborisade, F. (2008). Fiscal and budget management system: Principles, issues and debates. International Journal of Government Financial Management, 1(1), 19-32.

Adams, R. A. (2014). Public sector accounting and finance (4th ed.). Lagos: Corporate Publishers Ventures.

Adeyemi, F. K., \& Olanrewaju, O. M. (2019). Internal control system and financial accountability: An investigation Of Nigerian South-Western public sector. Economic Development Models of Emerging Countries, 1(1), 245-261.

Adongo, K. O., \& Jagongo, A. (2013). Budgetary control as a measure of financial performance of state corporations in Kenya. International Journal of Accounting and Taxation, 1(1), 38-57.

Ahrens, T., \& Chapman, C. S. (2006). Doing qualitative field research in management accounting: Positioning data to contribute to theory. Accounting, Organizations and Society, 31(8), 819-841.

Alade, M. E., Owabumoye, M. O., \& Olowookere, J. K. (2020). Budgetary control mechanism and financial accountability in Ondo State public sector. Accounting and Taxation Review, 4(2), 134-147. 
Aliyu, A. (2019). An evaluation of the application of budgetary control in The Nigerian Sub-National public sector. International Journal of Academic Research in Business, Arts and Science, 1(2), 86-105.

Avery, B. P., \& Obah, O. D. (2018). The impact of financial control on accountability in the Public sector in Nigeria. IOSR Journal of Economics and Finance, 9(6), 37-56.

Block, S. B., \& Geoffrey, A. H. (2008). Foundations of financial management (12th ed.). New York: McGraw Hill.

Drake, P. P., \& Fabozzi, J. F. (2010). The basics of finance: An introduction to financial markets, business finance, and portfolio management. Hoboken, New Jersey: John Wiley and Sons Inc.

Faleti, K. O., Faleti, H. O., \& Ojeleke, R. O. (2014). Budgetary and management control system for improved efficiency in public sector: The implications of "babariga-style" budgeting approach. Scholarly Journal of Business Administration, 4(2), 4452 .

Fasua, H. K., \& Osifo, O. I. U. (2016). Financial control and fraud prevention in the public sector. International Journal of Advanced Academic Research, 2(8), 34-48.

Institute of Cost and Management Accountant. (1999). Strategic management accounting. Journal of Management Accounting, $5(2), 37-45$.

International City/County Management Association (ICMA). (2013). Management's perceptions of annual financial reporting. A Policy Issue White Paper, Washington, DC.

Ironkwe, U. I., \& Okiakpe, E. K. (2017). Budgetary practices and accountability in Nigeria: A study of ministry of commerce and West Africa Glass Industry in Port Harcourt. International Journal of Innovative Finance and Economics Research, $5(1), 34-53$.

Jatau, U. V. (2008). Budget performance, evaluation, monitoring and control in a challenging environment. The Nigerian Accounting Horizon, 2(1), 191-196.

Khoove, R. (2010). Internal audit and risk management business advisory services; Measuring effectiveness of internal audit. Engineering Economics, 5(55), 70-76.

Lambe, I. (2014). Appraising the impact of budgeting and planning on the performance of financial institutions in Nigeria. Research Journal of Finance and Accounting, 5(16), 12-27.

Lambe, I., Lawal, M., \& Okoli, T. (2015). A systematic review of budgeting and budgetary control in government owned organizations. Research Journal of Finance and Accounting, 6(6), 1-10.

Okezie, B. N. (2004). Auditing $\mathcal{E}^{\circ}$ investigation-with emphasis on special classes of audit. Anambra State, Nigeria: Ayudo Press.

Olaoye, F. O., \& Ogunmakin, A. A. (2014). Budgetary control and performance in public Corporations in Osun State. IOSR Journal of Humanities and Social Science (IOSR-JHSS), 19(7), 59-62. Available at: https://doi.org/10.9790/083719745962.

Olomola, A. S. (2009). Strategies and consequences of budgetary reforms in Nigeria. Paper presented at the Paper for Presentation at the 65th Annual Congress of the Institute of International Public Finance (IIPF), Cape Town, South Africa.

Olurankinse, F. (2012). Due process and budget implementation: An evaluation of Nigerian public sector auditing. Asian Journal of Finance and Accounting, 4(2), 1-12.

Osanyintuyi, T. A. (2007). Budgeting and development policy in Nigeria. Retrieved from: http://www.scribd.com/doc/38540444. [Accessed 22/12/2021].

Owojori, A. A., \& Asaolu, T. (2009). The role of forensic accounting in solving the vexed problem of corporate world. European Journal of Scientific Research, 29(2), 183-187.

The Punch Newspaper. (2016). ICPC turns Farouk Lawan's co-accused to prosecution witness. Retrieved from: www.punchng.com.

Umeileka, N. (2013). Budgeting and budgetary control as toolsfor accountability in government parastatals. Unpublished Thesis. Caritas University, Enugu.

Walters, D., \& Dunn, J. (2001). Student's manual of auditing (6th ed., pp. 8:3.2-8:3.3). London: Thompson Learning.

Yang, Q. (2010). The impact of the budgeting process on performance in small and medium-sized firms in China. Doctoral Dissertation, University of Twente, Netherlands. Printed by: Print Partners Ipskamp, Enschede. 